\title{
Management Theories: The Contribution of Contemporary Management Theorists in Tackling Contemporary Management Challenges
}

\author{
Nadeem Hussain, University of Wales Trinity Saint David, UK, hussain.nadeem4545@gmail.com \\ Orcid No: 0000-0002-5853-8917 \\ Adnan ul Haque, University of Wales Trinity Saint David, UK, adnan@sribp.com \\ Orcid No: 0000-0003-2051-8635 \\ Akhtar Baloch, University of Karachi, Pakistan, abaloch@uok.edu.pk \\ Orcid No: 0000-0002-3216-9164
}

\begin{abstract}
Management theories have been the subject matter view for over the decades as there are schools of thoughts that affirms certain ways of managerial practices whereas other contradicts them. Three distinctive schools of thoughts included in this essay are namely, classical management theory, neo-classical management theory and modern management theory respectively. Classical theories emphasise heavily on scientific methods, administrative approach and bureaucratic structures for managerial practices while focusing on the task efficiency. On the other hand, neo-classical school of thoughts looked at the human's individual needs, their relations at work, behavioural aspects and motivations behind effectiveness. Lastly, the modern management school found "no one fit method for all situations" by considering systems, contingent approaches while organisational humanism and management science as core concept to operate in the dynamic environment. Additionally, the latest work of Foucault and Bourdieu is used to explain the modernity of management. The present trends and issues in the management practices are also addressed at the end.
\end{abstract}

Keywords: Classical Management School, Neo-Classical School, Modern Management Theory, Management Schools Of Thoughts, Issues And Trends In Management Practices

\section{Introduction}

Wilson and Thomson (2006) argued that 'History matters' and therefore, it is essential to develop better understanding about the present-day emerging trends and stages in the management since 19th century so that holistic view could be attained. To larger extent, there is an agreement that the management practices and approaches have altered with the passage of time (Bartol and Martin, 1998; Naranjo-Gil, Sánchez-Expósito and Gómez-Ruiz, 2016; Hodge, 2002). However, different school of thoughts have accredited it to several factors namely; globalization (Stros, Bukovinski and Coner, 2014), intense competition/survival of the fittest (Ferreira and Kittsteiner, 2011), connectedness (Pham et al, 2018), multiplicity (Cooper et al, 2017), socially constructed realities (Morgan, 1986) and so on. Having said that, the roots of management lies in the earlier management theories and therefore remains vital for tackling the contemporary management challenges.

After introduction, there are further three sections in this article.

First section contains the critical evaluation of management school of thoughts. Starting with the 'classical management theory' that includes notable work such as scientific management theory, administrative management and bureaucratic organisations. We explored that the core thought of this school emphasised on the management as 'scientific' way to attain economic efficiency by motivating employees via monetary rewards. Next school of thought discussed in this section is 'neo-classical theory' argued that motivation is always resulting from monetary rewards. Notable work of this school include; Maslow need of hierarchy, human relations and behavioural school, X-and-Y theory, and two-factor theory. It is found that the physiological and mechanical features being highly emphasized by the traditionalist led to a reaction from neo-classical school that focused more on human-orientation and largely paid attention to drives, time needs, attitudinal and behavioural aspects of workers. Lastly, the 'modern management theory' is discussed by looking into work of modern theorists such as, system theory, contingence theory, and organisational humanism. This school of thought argued that complexities, connectedness and context are contributing factors to organisations and therefore formed the modern management theory. This school considered logic and viewed management applicability to distinctive situations.

Second section explored the issues and trends in present management. The challenges faced by the modern-day managers are discussed through connectedness, complexities, and context.

Last section is a conclusion drawn from the critical review of the different management schools of thoughts and it is observed that the purpose of management theories remained on the effective and efficient management of resources in order to retain best talent and survive in the dynamic environment by using the approach and style that is in the best of organisational interest. 


\section{Management and Schools of Thoughts}

In simple terms, Drucker (1963) defined management as the product of effectiveness and efficiency where "doing things right" is regarded as 'efficiency' while "doing the right things" is considered as 'effectiveness' (cited from Robbins and Coulter, 2012). The theme of Drucker's definition is based on "knowledge work" (McGrath, 2014). On the other hand, Fayol defined it as, "to manage is to forecast and to plan, to organise, to command, to co-ordinate and to control" (cited from Prasad and Gulshan, 2011).

Different scholars have classified the management theories differently, such as Koontz (1988) divided it into six groups, namely, (i) The management process school, (ii) the empirical school, (iii) the human behavioural school, (iv) the social system school, (v) the decision theory school and (vi) the mathematical school respectively. On the other hand, Hitt et al. (1979) categorized it into three broader groups, such as (a) Classical management theory, (b) neo-classical management theory and (c) modern management theory. Following Sridhar's (2017) approach, this report considered second strategy and use three broader groups to explore and examine the distinctive theories under each school of thought.

\subsection{Classical Management Theory}

\subsubsection{Scientific Management Theory}

Classical theory is also known as traditional theory of management. The first among this school of thought (classical management perspective) is "scientific management perspective" where Frederick W. Taylor is known to be a "father of scientific management" for proposing 'one best way to do things' or scientific management/Taylorism (Ghuman and Aswathapa, 2010). Time and motion were a scientific analysis of task for examining the physical movements and requirements for the completion of task (Khurana, 2009). The idea of Taylorism is found to be consistent with the concerns of Adam Smith that emphasized division of labour bringing specialization, which leads to enhanced productivity (Khurana, 2009; Robbins and Coulter, 2012). In doing so the humans are treated as machines while ignoring the demoralizing and inhuman effects of tasks on the workers (Ghuman and Aswathapa, 2010). In addition to that, Taylor also commenced another study "science of shovelling" for determining the optimal weight to be lifted by the workers, thus, the optimal shovels were introduced to increase productivity while reward as increase in the pay was motivator (Ghuman and Aswathapa, 2010).

The major notion of the motivation for employees under scientific management were seen as money (Khurana, 2009). According to Furnham (2012), "money is an effective, powerful and simple motivator but it is not always motivator for everyone because at times it has power to demotivate" (p. 152). Additionally, Katzenbach and Khan (2010) argued that majority of the successful entrepreneurs agreed that major motivation is to be built upon something lasting rather than on the notion of making huge money. Furthermore, "Certainly great professional leaders like Marvin Bower, who built McKinsey \& Co., John Whitehead, the former Goldman Sachs senior partner, and Supreme Court Justice John Paul Stevens explained that that their motivation came from the work itself, and that the lasting respect of others was far greater than money as a measure of accomplishment. And very few great artists are in it for the money. Money is a by-product, and usually a secondary one at that, for such achievers" (cited from Katzenbach and Khan, 2010). Nevertheless, for lower level jobs, still money is often use as a basic needs (key motivator), reflecting that the scientific management is still applicable in the modern-day management.

During the same era, Frank and Lillian presented "applied motion study" focusing on reduction in the number of motions in a task in order to increase efficiency to have profit and satisfaction of a worker (Caramerla, 2018). Meanwhile, Henry L. Gantt developed a Gantt Chart to measure the productivity and working efficiency along with the task and bonus system of wages (Sheldrake, 2003). Gantt Chart also offered a graphical daily balance to ensure efficiency is routine manner (Sheldrake, 2003). Both above mentioned works were inspired by the concept of Taylorism. In the modern day, project management tools and techniques are used by organisations to ensure there is elimination of waste while attainment of most efficient results indicating the use of 'applied motion' in operations (Caramela, 2018). Program and review technique (PERT) charts are another modern-day managerial tool offering visual methods to administer time and resources of project (Sullivan, 2017). Nowadays, same scientific management approach is used with modifications as of now multiple websites offer online solutions through interactive sessions, free tutorials and blogs discussion, which are all based on Henry Gantt management theory (Sullivan, 2017). Harrignton Emerson stated twelve principles of efficiency that enables manager in defining objectives, developing scientific methods for evaluation, forming standardized procedures and rewarding employees (Sridhar, 2017). The major drawback of this school of thought is that it treats and views worker from only the lens of economics whereas workers' behaviours are not always directed by financial needs as there are other needs such as social, security and esteem needs (Sridhar, 2017). In addition to that, there multiple methods to commence task rather than relying on "one best way" because the situation differs and even two individuals could carry out similar job differently (Sridhar, 2017). 


\subsubsection{Administrative Management}

Under same classical school of management, the contemporary school of thought to scientific management are the 'administrative management' and 'bureaucratic organisations' (Robbins and Coulter, 2012; Sridhar, 2017). This school of thought is based on traditional or administrative principles of management while prominent exponents include Henri Fayol, Chester Barnard and Colnel Urwick (Sridhar, 2017). Henri Fayol is considered as the father of modern management for his contribution in the administrative management field primarily focusing on the operational approach through 14 principles of management. "Fayol introduced unified concept by focusing on managerial levels and the organisation as a whole" (Sridhar, 2017). All business activities could be split into six groups namely; administrative, security, accounting, financial, commercial and technical while focused on the "managerial activities of manager including, planning, organizing, directing, coordinating and controlling" (Robbins and Coulter, 2012). Key principles include "division of work, authority and responsibility, discipline, unity of command, unity of direction, subordination of individual interest to general interest, remuneration, centralization, scalar chain, order, equity stability of tenure of personnel, initiative and esprit de corps" (Robbins and Coulter, 2012). Fayol's heavily emphasized on rationality, logic and consistency (Sridhar, 2017).

Interestingly, "Taylor worked from the bottom of the hierarchy upward, whereas Fayol worked from the apex downwards, with 'management centred' philosophy", which is the difference between two classical schools of thoughts (Sridhar, 2017). On the other hand, Chester Barnard argued that effective communication is essential for cooperation and there should be a balance between rewards and contributions among workers (Robbins and Coulter, 2012). Colonel Urwick assembled the principles of Taylor, Fayol and other management scholars and suggested that management is a dynamic process to perform organisational activities (Sridhar, 2017). This school of thought also has limitations as many of the principles have dilemmas and are contradictory. For instance, limited span of control and division of labour contradicts number of organisational levels being smaller or principle of specialization is contradicted by unity of command (Sridhar, 2017). In addition to that, when seeking specialization, it is not possible to follow simultaneously all modes. There is lack of empirical testing of these principles at organisational setting. Moreover, all principles being valid under all situations is not practically applicable. Lastly, mechanistic organisational structure develops due to the outcome of these principles, that are insensitive to psychological and social needs of the employees (Sridhar, 2017). Nevertheless, Brown (2014) argued that Henri Fayol's 14 principles of management promoted efficiency through division of work, which are still recognised idea in the present day. Additionally, "Fayol acknowledged employees' needs through adequate remuneration, stability of tenure, equity, team spirit and initiative are all essential albeit coming from top down direction" (Brown, 2014). Hence, Fayol has not ignored the employee perspective in the organisational context but yet the major criticism Fayol attracted is that it is flatter in present era (Ibid). However, although, it appears less applicable to some extent in modern day work environments. Moreover, even in modern era, Fayol offers a good start for the managers and organisation to learn about approaches, structures and managerial functions (such as planning, forecasting, organising, directing, coordinating and monitoring) (Brown, 2014). Having said that, these were further taken into consideration by theorists from human relation school.

\subsubsection{Bureaucratic Organisation}

With the expansion of organisations, the operations become further complex giving "authoritarian-paternalistic pattern" way that enhances functional specialization within the distinctive layers of management to have smooth operations (Sridhar, 2017). This led to bureaucratic approach towards organisational structure and Max Webber proposed a theory of bureaucracy for organisational efficiency based of organisational systems functioning on set of rules, policies and hierarchy of authority (Ibid). Biggest fain of this approach is that it excludes the conflict or overlapping duties, which offers clear direction so that organisational operations gain efficiency in productivity. The approach offers consistency in patterns to ensure higher precision in tasks to avoid waste of resources (Sridhar, 2017). This is effectively the theme of modern-day organisations too to have structural and patronized functions in order to avoid wastage of resources and enhance operational efficiency (Brown, 2014). However, the major focus of this theory remains on positions rather than individuals (Sridhar, 2017). Organisations would even continue its functionality even if workers quit, which is visible in modern day to some extent that organisation stays while employees come and go (Brown, 2014). Excessive red tapism and paperwork often creates unpleasant experience as well as delay smooth operations (Sridhar, 2017). Higher emphasis of policies and procedures develop the cautious approach and as a result employee avoid risk and show less creativity, initiative and growth (Ibid). In addition to that, humans are not machine and therefore would differ in their approach and performances while this school of thought expects behavioural conformity at the expense of performance.

The classical school of thoughts/traditionalists considered theories of management could be deduced by means of observation and analysing managers do while empirical findings have distilled in reaching for specific principles (Sridhar, 2017). Furthermore, this school is criticized for executing practices of past, which include outmoded and mediocrity. Despite that, it is the leading school of thought and largely prevalent in managerial practices (Ibid). 


\subsection{Neo-Classical Theory}

Neo-classical school of thoughts argued that traditional theory and its principles are contradictory, only focused on motivation through monetary rewards and proposed approaches to carry out operations without taken into consideration the time factor, which is subject to alteration (Sridhar, 2017). The physiological and mechanical features being highly emphasized by the traditionalist led to a reaction from neo-classical school that focused more on human-orientation and largely paid attention to drives, time needs, attitudinal and behavioural aspects of workers. Human relations school and behavioural school formed under neo-classical theory (Robbins and Coulter, 2012; Sridhar, 2017).

\subsubsection{Human Relation School}

Elton Mayo is the main champion along with the Frank Roethlisberger and William Dickson of human relations movement that later transformed into organisational behaviour. They argued that inter-relationships within the group members are vital aspect at the organisational settings (Robbins and Coulter, 2012). Their study known as "Hawthorne experiment" proved as paradigm shifter in the management studies.

In actual, "Hawthorne Effect" is a term explaining the phenomenon of individuals work and demonstrate better performance when they are observed (Cherry, 2018). Since the experiment took place at Western Electric's Hawthorne company therefore phenomenon is termed after the location (Ibid). The experiment was conducted to assess whether there is a correlation between productivity and work environments (such as light, break duration and length of day work). It was evident that employee's productivity tends to enhance due to change during the experiment however, it declines when experiments ends. The experiment proved vital in establishing the key notion that increased attention from the head/supervisor is reason for improved performance (Robbins and Coulter, 2012).

Follow up interviews with the workers revealed that individuals do not leave their attitude, emotions and feelings back home as they do not only work for economic gain. Their motivation to work was not only confined to economic benefits but a good treatment, healthy work environment and autonomy to do things in their own way motivates them to do better at work (Robbins and Coulter, 2012). "The two important conclusions drawn from this experiment were (a) existence of strong informal groups and (b) behaviour of employees at work is significantly affected by non-economic factors" (Sridhar, 2017). Hence, this work contradicts the earlier work of classical theory that argued employees are economic and rational beings whereas human relations school revealed employees' social person view. Additionally, social person view opposed rational economic view as study revealed social needs motivate employees, interpersonal relationship develops sense of identity among employees, fatigue and boredom enhance due to repetitive routine and structured tasks, social forces make employees more responsive towards work rather than management control and incentives, and participative management increases employee motivation towards assigned tasks (Robbins and Coulter, 2012).

Due to this theory, the concept of social managers emerged and evolved which is why at present the managers role is visible as coach or helpers to manage employees at workplace. Thus, the recent trends of human relations are widely visible in the modern day of managerial approach. The theory also proved a milestone in looking beyond organisational/environmental factors by exploring the social and individual psychology of workers working at workplace (Robbins and Coulter, 2012). Furthermore, the experiment revealed that individual's psychological needs have a vital role on the individual and collective performances. People orientation is essential as employees given attention performs better irrespective of the working conditions (Ibid). In summation, the greater output is resultant of employees' satisfaction of needs and desires. As the theory focused on better communication and concept of powering the employees to participate in decisions results in organisational success. These are largely evident in the present day too as now the organisations such as Google, LaFosse and Pets at Home uses the concepts of human relations to ensure greater output (Goldfingle, 2012). Although, this study rejected the concept of Taylorism's degree of specialization, structured programme and rigid hierarchical control but it does not oppose all ideas of classical school, therefore, it is regarded as neo-classical school.

Interestingly, Sridhar (2017) concluded the notion of human relations approach as, "this school emphasized that treat employees as if they are important and give the workers the feeling of participation" (p. 10). One of the key limitations of this theory is that it keenly focuses on human variables as most important critical attribute while ignoring all other attributes. Additionally, focuses on symbolic rewards while ignores role of material rewards (Sridhar, 2017). The approach focuses on individuals and small groups instead of large organisations. Moreover, the effective communication and interpersonal relationship is effective for lower level of organisation rather than other layers of management (Robbins and Coulter, 2012). "It could be argued that the movement of this approach has accepted several assumptions of traditionalists and does not accomplished a major breakthrough in management theory" (Sridhar, 2017). However, it contributes to open a passage for behavioural school of thought.

\subsubsection{Behavioural Schools}

As stated earlier, the Hawthorne experiment led to the inclined interest in behavioural science within the management, leading to transform human relations approach into modern behaviourism (Robbins and Coulter, 2012). Psychological 
considerations remain key aspect while suggesting that primary economic objectives are attained through completion of emotional needs. Interestingly, Sridhar (2017) stated that behavioural schools could also be taken into consideration under the modern organisational humanism within modern management theory. Thus, this indicates that most of the aspects of behavioural schools are relevant in the modern-day management theories. There are number of scholars such as, Abraham Maslow, Douglas McGregor, Frederick Herzberg, Kurt Lewin, Mary Parker Follet and so on who had contributed to behavioural school (Haynes, 2013; Robbins and Coulter, 2012; Rogers, 2006; Sridhar, 2017). However, not all of them could be specifically classified as neo-classical theorists because several of those scholars have contributed towards modern management theories either in general perspective, modern humanism, or social system theory. Some of the most widely studied are discussed in this report.

\subsubsection{Maslow's Hierarchy of Needs}

Abraham Maslow categorized as well as prioritized the total five types of employee needs. The pyramid of needs had the most basic needs at the bottom and term them as "physiological needs" such as, sleep, eat, water, sex, breathing and other physical needs (McLeod, 2018; Robbins and Coulter, 2012). With the attainment of these needs, second need arise namely, "safety needs" as the previous needs do not remain motivators. The basic safety, protection, stability and no fear remain the concerns of the individual. If a person's safety needs are not satisfied then they work as motivators (McLeod, 2018). On the other hand, Robbins and Coulter (2012) argued that Maslow explained that security needs include the protection for physical as well as emotional harms that arise physiological needs are met. "Belonging and love needs/social needs" develops after the physical and safety needs of an individual has been satisfied (McLeod, 2018). This is a need of an individual that he/she wants a social support and acceptance, love, and friendship in the society (Robbins and Coulter, 2012). It is also considered as the prime motivator for the individual after physical and security needs remain no longer motivator, and therefore, he/she develops a meaningful relationship with others.

The internal esteem attributes including, autonomy, self-respect and achievement needs external esteem like attention, recognition, and status work as motivators for the individuals under "esteem needs" (Robbins and Coulter, 2012). In order to attain this need, individual requires to develop self-confidence so that glory, fame, status and reputation could be achieved (McLeod, 2018). The esteem needs are often the key motivator for employees working in the organisations. "Self-actualization needs are related to attainment of one's own potential, growth and self-fulfilment that drive him/her to become what he/she is capable of becoming" (Robbins and Coulter, 2012). Maslow argued that after the satisfaction of one need, individuals inclined to another level of need while only one type of need work at a time (Robbins and Coulter, 2012). Alderfer (1969) criticized the work of Maslow by stating that multiple needs can work together rather than one need at a time (Robbins and Coulter, 2012). For instance, physiological and security needs can both work at a time on individuals. In addition to that, Maslow ignored the environmental factors by considering the needs occurring in static manner whereas in actual, environmental factors tend to vary due to constantly change in the dynamics.

\subsubsection{Theory $X$ and Theory $Y$}

Douglas McGregor in his book, "human side of enterprises" published in 1960 argued that there are two types of individual in the organisation, respectively X and Y type (Robinson, 2010). Theory X managers have a negative view of workers and perceived them as untrustworthy, lazy, and lacking the initiative to take responsibility (McGregor, 1960; Robinson, 2010). Therefore, such types of managers are more autocratic and rigid in their respective approach. The employees are seen to have low or no motivation to take initiative by their own, thus, require set of directions to execute tasks. On the other hand, Theory Y managers view employees are trustable and have the potential to take a charge of responsibility. Furthermore, the employees are highly self-motivated (Robinson, 2010). The Y type managers are participative and democratic in their style and thus motivates employees by involving them actively in their routine tasks (Ibid). In modern era also there are examples of theory Y managers. For instance, WL Gore and Associates is an organisation that highly encourage managers to work as coach in encouraging employees to be creative and self-initiators. Festejo (2012) argued that employees tend to perform better when allowed to exhibit their creativity with no restriction. Smith (2010) argued that for lower/operational level employees Theory X managers/supervisors are more effective because the productivity to achieve specific unit production is attained when there are directions given from the top. Grandey (2004) argued that Theory X managers mainly focus on task accomplishment while Theory Y is keen on fulfilling employees' motivational needs but still the focus is to achieve productivity rather than measuring the well-being of employees. Furthermore, Theory Y also comes under the criticism that it is a deliberate approach to take more out of employees so that there is increased productivity (Grandey, 2004). Care for employee is subject to their productivity at work and economic benefits of the organisation. Barnett (2017) argued that in the 21 st century still the theory is practically visible as there is higher focus on self-managed workers and as a result they are involved in such programs so that they are more creative and willing to take initiatives, which are aligned with the aspects of Theory Y. 


\subsubsection{Herzberg's Two Factor Theory}

Two factor theory is also regarded as motivation-hygiene theory and dual-factor theory proposed by Frederick Herzberg in 1959 (Robbins and Coulter, 2012). The main notion of the theory is that there is an association between intrinsic factors and job satisfaction while linkage is between extrinsic factors and job dissatisfaction (Herzberg, 1966; Robbins and Coulter, 2012). Traditionally, it was viewed that satisfaction and dissatisfaction were the two ends of one node, but Herzberg altered this by proposing that "satisfaction" and "dissatisfaction" are the two different ends of two distinctive nodes (Ibid). This means that it is not necessarily right that a person who is not satisfied is always dissatisfied and vice versa. To support this argument, he proposed 'hygiene factors' as one set that takes employees from dissatisfaction to no dissatisfaction while 'motivators" are another aspect that takes employees from no satisfaction to satisfaction (Robbins and Coulter, 2012). In other words, Herzberg argued that an elimination of dissatisfying attributes related to job would not always make job further satisfying and vice versa. Thus, to motivate employees, there should be motivators (such as, achievement, recognition, work itself, responsibility, advancement and growth) because hygiene factors (supervision, company policy, relationship with supervisor, salary, working conditions, relationship with peers and subordinates, status and security) would only help in removing dissatisfaction while motivators would alter the behavioural aspect of employees to be more committed and satisfied, that would eventually improve the organisational productivity (Ibid).

One of the most relevant examples of two factor theory is evident in the fact of Siemens where hygiene factors as well as motivators are used to retain employees (Tuttle, 2003). The motivators are specifically used to ensure employees remain committed and engaged to their assigned tasks while given substantial space to demonstrate their own creativity (Ibid). The involvement of emplyoees in the task improves their capabilities and enhance the level of satisfaction that further improves the organisational efficiency (Tuttle, 2003). The flexible work environment and improved working conditions brought positive results for Siemens through introduction of hygiene and motivating factors in the job description and specification (Ibid). Thus, it could be said that this theory is still relevant in the $21^{\text {st }}$ century of management of employees at workplace. However, this theory also has its lacking and one of the major criticisms this theory has received is that is rather simplistic in its procedures and methodology (Robbins and Coulter, 2012). Yet, this is the most important theory that is incorporated practically in the organisations at present by using it in designing job. It helps in job enrichment to ensure the workers have the set of both hygiene and motivators when working in the organisational setting.

\subsubsection{The Management Theory of Lateral Process Within Hierarchy}

Marry Parker Follet is regarded as the "Mother of Modern Management" because of her contribution to the management field (Caramela, 2018). The epicentre of her theory is that "management is the art of getting things done through people" (Caramela, 2018). Direct contact, early stages, reciprocal relationships, and continuous process were the practices of coordination that enabled Follet's management theory to have lateral movement within the organisational hierarchy (Caramela, 2012). According to Follet's theory, it is essential to have a direct contact between the managers and workers in order to have smooth relationship while avoiding the misunderstandings and conflicts that hinder the organisational process as well as efficiency (Ibid). Additionally, theory also proposed the meetings at regular interval and constructive discussions at workplace are key to practically implement smooth operations. Furthermore, at the very early stage, coordination should be developed so that there is no waste of resources such as time, money and energy (Ibid). Coordination is essential to ensure that all employees feel equally important and are prepared for the next stage in order to support and complement one another. Another practice is to have reciprocal relationship at workplace so that every employee irrespective of the hierarchical position is responsible for doing the task and integrating with the organisation's other remaining parts/departments (Ibid). This is the lateral movement within the hierarchy that results from the coordination and direct contact among employees and the management. It is also essential that all workers are doing equal to have a team effort, in case of anyone doing more of less would shift the burden on few, leading to unstable operations (Caramela, 2018). Lastly, it is essential to ensure coordination is a continued process, if it is only carried for specific time then the disturbance would develop (Ibid). It is important to channel the coordination in every dimension and every step that management takes for its operations.

Known for her mediating tactics, Follett developed her management theory on the principles of integration, power with and group power (Robbins and Coulter, 2012). The principles of According to Follett's theory, it is important that employees at all layers of the management are integrated with the organisational goals. This helps in eliminating conflicts and a conscious effort is used to work as a team and move in one direction rather than being in a freefall stage (Caramela, 2018). The desired results are attained by the organisation due to such integration. Often the organisation also expands through horizontal integration by adding different units to build a successful enterprise. Furthermore, it is also vital that rather than having rigid hierarchy, there should be delegation of power to specific people, who have the ability to make fruitful decisions (Caramela, 2018). The concept of Follett is "co-active power" as this way team feel better that they are valued and take own initiative rather than being directed to do tasks (Ibid). However, at the same time, Follett also argued that structural hierarchy is equally important for the organisation. Moreover, Follett argued that instead of personal power, there should be group power because organisations are not existing to benefit one person, but to be beneficial for all the 
workers (Ibid). Due to this thought process, there is higher team work rather than competition among workers (Caramela, 2018).

Follett's theory is applicable in the present day too because there are evidences of organisations being successful due to higher integration and power sharing (Caramela, 2018). For instance, Walt Disney Company uses horizontal integration by buying distinctive sources of creative things such as Lucasfilm, Marvel Comics and Jin Henson Studios, which helped the company in creating successful and iconic characters (Hanks, 2018). This happened due to integration within the different units of the organisation.

\subsection{Modern Management Theory}

The complexities, connectedness and context are the three main features of the organisation that have shaped the modern management theory (Haque, Aydin \& Uysal, 2017; Sridhar, 2017). In addition to that, the individual and organisational diverse needs, aspirations, motives and potential equally play their part in the modern management theory (Robbins and Coulter, 2012). Thus, this is the reason for flux, interdependence, ambiguity and multiplicity are the elements that has expanded the complexities in the dynamics where organisations operate and functions (Maznevski and Medenhall, 2004). The consequence of these aspects is that having one universal management principles template for all types of organisations and individuals become rather impractical and inapplicable (Sridhar, 2017). Hence, such complexities drive the organisations to develop flexible strategies and managerial principles to deal with work and workers at workplace. In addition to that, the modern management theory considers complex employee view that is opposing to rational economic man view of classical theory and neo-classical theory's social person view (Sridhar, 2017).

Organisation-centre was the theme of classical theory revolving around efficiency along with functional approach following deductive reasoning. On the other hand, person-centric approach was focus on neo-classical school emphasizing on experimental descriptive aspects following higher deductive reasoning. Nevertheless, revisionists followed behavioural and quantitative dimensions while adopting inductive reasoning with rigorous complete experimentations. The modern school of management largely considered logic and viewed management applicability to distinctive situations (Sridhar, 2017). In the era of digitalization and computer usage, quantitative methods were used to assess the role of management in modern day organisations (Hodgetts and Altman, 1981).

\subsubsection{System Theory}

As discussed earlier, both; classical and neo-classical theory have largely focused on one aspect at the expense of other. For instance, the 'efficiency', 'structure' and 'task' are the core theme of classical theory whereas 'people' is centre theme of neo-classical theory. Considering the limitations of both, modern theory intakes the balanced root to investigate the management practices. The first theory in modern school of management is system theory that offers a holistic view "organisation as a whole" (Sridhar, 2017). System as an entity reflects coherent whole (Ng, Maull and Yip, 2009), implying an exchange of dialogue between "holism" and "reductionism" (Mele et al. 2010). Thus, it conveys the multidisciplinary viewpoint from several context including, economic, society, nature, information technology and institutions (Mele et al. 2010). The management's problems are tackled through the integrated approach where focus remains on systems serving people. The prominent authors of this theme include; Chester Barnard, George Homans, Philip Selznick and Herbert Simon (Sridhar, 2017). Two or more interdependent parts constitute a system where all interlinked parts function to make things work. In fact, organisation is viewed as a human body where all parts function together to function properly. Hereby, interdependent parts are very significant and indicates that the emphasis of the managers or supervisors shall not be limited to one specific single cause but consider the holistic view as different factors combine cause problem (Sridhar, 2017). Open and closed are two types of systems. According to Sridhar (2017), “An open system interacts with its environment such includes; all biological, human and social systems whereas several mechanical and physical systems are regarded as closed systems". Interestingly, organisation as a closed system is view of traditional organisational theorists whereas organisation treated as an open system is a viewpoint of modern theorists (Sridhar, 2017). It reflects that modern-day organisations are consistently interacting with its environment on regular basis. In other words, "an organization is an open system that interacts regularly with external forces namely, government agencies, suppliers and customers" (Sridhar, 2017). These different stakeholders affect the practices of the organisations.

Mele et al. (2010) argued that system theory applications in management could be found in several dimensions such as it focuses on complexity, adaption, relationships, environment, quality, value and knowledge. The organisation viewed as learning system reflects the vision of knowledge produced through set of skills and competencies (Nonaka and Tacheucki, 1995). "Knowledge is at the core of an autopoietic process of resource generation, creating resourcebehaviour-resource cycles where cognitive schemes allow the entire system to function" (Mele et al. 2010, p. 130). Considering value approach, "the organisation is viewed as a holistic system with higher degree of integration between the factors intervening in the process of value creation" (Grant, Shani and Krishnan, 1994). It indicates the that subsystems such as R\&D activities, routine research, feedback, and quality management are results of network (Polese, 2004) resulting from different system actor's (stakeholders) contribution (Alter, 2008). The focus of organisation on quality links the system thinking with the concept of total quality management (Kim and Burchill, 1992). The focus on quality 
strengthens the relationship between different parts of system enhances tendency to achieve goals (Mele and Colurcio, 2006). If an organisation is a system at micro level, then at macro level environment is a system (Mele et al. 2010). The action of employees amplifies for survival when operating at micro and macro level. In a viable systems approach (Barile and Polese, 2010) in order to survive in the continual dynamic process organisation, need to adapt to internal changes (following adaptation). This reflects that the modern organisations to larger extent still follows the earlier theorists' notion of focusing on "set of skills and competencies", "quality", and "specialization" to ensure tasks are carried out in effective and efficient manner.

\subsubsection{Contingency Theory}

Effectiveness is contingent as it depends on the interplay between managerial applications and behaviours and particular situation (Fielder, 1970). Organisational behaviour is studied through contingency theory approach by elaborating on contingent factors namely, culture, technology and external environment affecting the functionality and design of the organisation (Islam \& Hu, 2012). Sridhar (2017) argued that modern-day organisations are more complex and therefore one specific managerial strategy could not be applied to all types of situations. Hence, the emphasis of contingency approach is on the adaption of managerial strategies as per the need of situation. In other words, each situation should be viewed separately, and the plans should be made while taking into consideration a wide range of internal and external factors to administer the context, connectedness and complexities of the dynamic environment. Based on the scenario, a best fit of the managerial approach for the situations should be implemented. This theory emphasises on the postulate that organisational outcomes are resultant of a fit between two or several factors (Van de Ven \& Drazin, 1985; Islam \& Hu, 2012). Nevertheless, the focus of this theory remains on the organisational design (Luthans \& Stewart, 1977).

Interestingly, Sridhar (2017) explains that as per this approach, theorists have made an attempt to assimilate several thoughts of various management schools because it was obvious that alone those concepts and principles would not be universally applicable under all situations. Thus, it could be argued that considering the contingent approach, the practices of modern-day organisations have roots from the earlier schools of management because the integration of various schools of management are combined to enable the managers for effective managerial practices in distinctive situations. As a result, this theory also stressed on the importance of development of managerial skills to deal with situational factors (Sridhar, 2017). One of the notable works is of Hersey \& Blanchard's (1969) "Life Cycle Theory of Leadership", which argued that the role of manager/supervisor reduces with the increase learning capabilities and efficiency of the employees. In other words, as the situation vary, so does the role of manager also change because of the maturity of the employees and change in the organisational dynamics. In other words, practical selectivity and situational sensitivity should be developed by the managers (Sridhar, 2017). Presently, the contingent approach is practiced ensuring there is structural organisation while leading the workforce through motivating them (Sridhar, 2017). On the other hand, planning information decision systems, control systems, development of communication channels, decentralized decision-making and employee training and development are some of the potential areas where contingent approach is evident (Sridhar, 2017). Thus, it indicates that the theory focuses on the behavioural motivation, which is the focus of neo-classical school and the results of such motivation is driven from the interactions with the different environmental factors. Those factors play its part in motivating employees to demonstrate individual excellence so that organisational goals are attained in effective and efficient ways, hinting towards focus of task-orientation (reflecting the traditionalists' school of thought).

Contingency approach argued that flexibility in leadership style and acting according to the need of situation lead to influence employees do well at workplace (Islam \& Hu, 2012). It indicates the motivational factor of Herzberg's theory that interpersonal relationship leads to productive workforce. Therefore, the root of this approach is largely linked with the earlier school of thoughts of management. Sridhar (2017) stated that the champions of this theory confirmed that environment is complex and dynamic, which requires flexibility in the organisational design and structure and therefore, bureaucratic structure could not be effective in such situation. Although, this approach has widened the scope of leadership practices but the theory comes under the criticism that this approach is more straightforward while situations could be tricky as number of factors could emerge in the middle of process and in search of perfect solution there could be wastage of invaluable resources such as time and money. At times there could be superficial decisions due to time limit rather than going deeper into the situation. Since, it takes a situational context, there is a problem that what leaders do is based on the situation. Hence at hindsight what may appear viable in a particular situation might not be the best for the company in a long run because of change in the situations. Thus, this approach is not feasible in all situations.

\subsubsection{Modern Behavioural School/Organisational Humanism}

Sridhar (2017) argued that organisational humanism is the extension of neo-classical theory's behavioural school due to larger commonalities between them. The modern behavioural school has more worked from the champions such as Abraham Maslow, Douglas McGregor and Chris Argyris as the school is based on their philosophies (Sridhar, 2017). Doucet (2017) argued that higher emphasis of organisational humanism is on the usage of intrinsic motivation for personnel's growth, which leads to increase organisation's economic efficiency. The philosophical stance of this school largely rests on the individual needs driving to use their creative skills and capabilities in the organisational setting. 
Hence, the foundation of this school rests on "self-actualization view" (Doucet, 2017). As per this view, self-actualization drives the individuals to exhibit their best at work because they are valued and have the maturity to take initiative by being self-controlled and self-motivated (Sridhar, 2017). Hereby, the inner potential of the employee is known to him and it is used effectively to achieve the organisational goals (Doucet, 2017). Moreover, this school of thought also considers that structural tasks and routine jobs as part of rational organisational design limits the motivated potential and creative skills of employees. Thus, in order to remain consistent with the human nature, organisations should avoid the rigid design, unimportant rules and inflexible supervision (Sridhar, 2017).

Higher freedom at workplace leads to have greater satisfaction (Doucet, 2017). The organisational benefits are produced by highly motivated self-actualized employees, which are not likely achievable under bureaucratic organisations. This school also emphasis on the manager's role in strengthening the decision-making abilities of the employees while giving them opportunity to take initiatives and challenging them. As stated earlier, the internal motivator of the employee for growth is key feature of humanist approach, which is also opposite to external pressures such as organisational play and social acceptance that are prominent themes of traditionalist and neo-classical schools of thoughts. Individual needs and the fulfilment of those needs are the focus of organisational humanism. However, this approach comes under a criticism that it considers each and every single employee in the organisation looks for self-actualization in the organisational setting (Sridhar, 2017). As previously, the work of McGregor (1964) showed that there are X type and Y type individuals, so it is highly likely that all individuals look for self-actualization at workplace. In addition to that, organisational humanists argued that in several ways individual at workplace can make work entertaining by making their jobs interesting (Sridhar, 2017) whereas this could be agreed to certain extent but not always because some tasks are time bounding creating higher stress and focus of the employees is on the completion of task rather than making it interesting. For instance, in the project-based organisations, there is a certain deadlines and employees cannot focus on making it entertain instead of completing it in timely manner.

\subsubsection{Management Science}

Core concept of the Management Science school of thought is "Operational Research Teams to deal with complexities, connectiveness and context" (Sridhar, 2017). One should not confuse management science with scientific management classical school as the two are different. Nevertheless, management science intakes quantitative approach evolved from scientific management techniques' applications (Sridhar, 2017). Due to the organisational complexities, a modern-day manager requires more calculative approach and information to take rationale and effective decisions (Luthans \& Stewart, 1977). Hence, this approach proposes the quantitative techniques for making such decisions (Luthans \& Stewart, 1977). Different quantitative tools and high-speed computers are used for dealing with voluminous data to be computed in a manner so that information is analysed to give appropriate options for making decisions (Sridhar, 2017). Operations Research Teams included scientists from interdisciplinary groups during the World War II so that complex problems of war could be tacked in appropriate manner (Sridhar, 2017). Under this approach, mathematical models were constructed to deal with real life problems while altering the variables' values so that the effect of change could be calculated for making rationale decision-making (Sridhar, 2017). Quality control tools, inventory-control, PERT, CPM, simulation models, queuing theory, and linear programming tools are used under this approach because of the higher emphasis on rational and objective decision-making (Sridhar, 2017).

"Objective rationality reflected the capacity and readiness to undertake a largely scientific, which is unemotional and based on reasoning linking the means with ends while consider the the impact of decision on environment in totality aspect" (Sridhar, 2017). Thus, it could be argued that this approach is more focusing on perfection and precession by expressing the relationship between variables through quantitative mode. However, widely the applications of management science are evident in the managerial practices especially in planning and controlling activities, but, yet it could not be attributed to all types of managerial process. For instance, staffing, leading, and organizing by nature are more human instead of technical so the quantified applications cannot be applied to them in all aspects. This is one of the biggest limitations of management science approach.

However, modern management theories are more dramatic developments since 1900 (Sridhar, 2017). Open systems, managerial actions with degree of contingency, organisational designs shaped by wide range of individual needs and the usage of sophisticated quantitative tools for managerial decisions are some of the most important concepts of the modern management theory, having roots in the traditionalist and neo-classical theories (Sridhar, 2017).

\subsubsection{Post-modern to Modernity Era}

In the modernity era, there is a shift from post-modern management (Bazrkar, Heravi and Abedzadeh, 2014). With the capitalism's emergence as manifestation modernism developed on the concept of "reason" to deal with micro and macro level social influence (Rahman Serest, 1998). In short, modernity is the era of knowledge of human and depends on various principles of "best practices" (Bazrkar et al. 2014). Michel Foucault, Jean-Francois Lyotard, Charles Jenks, Ahab Hassan and Gilles Deleuze are main thinkers of postmodern era (Thompson, 2004). Within social sciences, 
postmodernism often emphasizes on the desires and instincts along with factors such as reason and counter reasoning and motivation (Thompson, 2004).

\subsubsection{Foucault Management and Organization Theory}

In is essential to examine the subjectivation perspective of Foucault's philosophy (Bazrkar et al. 2014). According to Foucault (1994), "way a human being turns him or herself into a subject" (p. 126). Various ways are used by societies while providing the distinct prescriptions for people transformation into subjects (Bazrkar et al. 2014). Subjectivations is a power technique that enables the people transformation into subjects (Bazrkar et al. 2014). Foucault (1994) explained subjects have two meaning, that include firstly, "control and dependence" and later "identity and conscience". Hence, it reflects that subjects are treated as controlled and dominated objects that institutions and society wanted them to be (Bazrkar et al. 2014). Moreover, identity and conscience tied subjects although they are free and independent, but society and institutions construct their identity and conscience (Bazrkar et al. 2014). Additionally, Foucault considered individualizing technique in relation to subjectivation that differs from power technique as "oriented toward individuals and intended to rule them in a continuous and permanent way" (Foucault, 1994, p. 181). McKinlay and Starkey (1998) argued that Foucault Management and Organization theory explains the techniques and observation along with the performance appraisal and measuring effectiveness in the private sector modern organisations. Hence, in this regard, "Weber's metaphor of 'iron cage' of modern rationality that simultaneously materially enriches Western civilization and spiritually improves the capital individual" (Thompson, 2004). In other words, Foucault's work considers technologies important aspect for theoretical construct that affect the subjects while internationalization of power is through modern subject (Thompson, 2004).

Foucault is a clear thinker from "postmodern" school by reflecting the organisational contemporary life is not always "part of some modernist march to a better tomorrow" (Thompson, 2004). Another important development of Foucault in criticizing to organisational rationalization by stating that, "the development of disciplines of knowledge shaped almost wholly by the 'disciplinary gaze' of surveillance" that formulates the categorization of "individuals or bodies .... through diverse and localized tactics of ratiocination" within modern organizations" (Clegg, 1998). Nevertheless, discipline is essential attribute of the Foucault's theory that is effective in the improvement, development, training and transformation of body so it could be adequately used (Thompson, 2004). Modern man is constructed through tool of modern society 'discipline' which transformed him/her in to productive, submissive, trained and educated individual (Bazrkar et al. 2014). Interestingly, early organisations consider time and space in ensuring human body is disciplined in transforming into docile body, thus, enclosure and partitioning is vital in facilitating communication between workers and the authorities (Thompson, 2004). On the other hand, modern organisation uses examination, normalizing judgement and hierarchical observation for training discipline to create docile bodies (May, 1998). These attributes bring effective control and maximum efficiency in the operations through balanced power, discipline, identity and consciences.

\subsubsection{Management and organisation studies- Pierre Bourdieu}

Bourdieu's work is regarded as "theory of practice" that contributes to the field of management and organisation through habitus, capital and field and it also proved path-breaking into the area of organisational field and social capital (Greenwood and Meyer, 2008). "His work contributes towards the overcoming of binary opposition between objectivism and subjectivism through a structuralist constructivism" (Ozbilgin and Tatli, 2005). Bourdieu used applied stance as a practical lens for setting strategy-as-practice community (Splitter and Seidl, 2011). Bourdieu argued that culture and society are mainstream to explain structuralist and hermeneutic details (Ozbilgin and Tatli, 2005). Moreover, he explains that habitus, practice and structure have a relationship while power has a vital role in conceptual planning of structure and habitus. The use of dualistic transition of objectivism and subjectivism has been criticized by others stating that it is a superficial attempt to bridge social phenomena's rational properties (Ozbilgin and Tatli, 2005). Interestingly, Bourdieu advanced a case against deconstructionist approach of post-modernism within social sciences by stating reality doesn't change due to theory (Bourdieu, 2000).

Using the concept of habitus, Bourdieu explained the internalized mediating mechanism while transformation and changes in structural principle of culture are due to observed autonomy (Bourdieu, 2003). Furthermore, Bourdieu (2003) that argued reflective practices within the research to consider both epistemological stance and methodological questions related to social inquiry. This led to the formulation of "an alternative conceptual framework for multilevel organisational research" (Ozbilgin and Tatli, 2005). The introduction of social bias and logic of practice to negotiate abstract structures within organisations (Ozbilgin and Tatli, 2005). Moreover, the relational philosophy is refined by Bourdieu for using concept and actions of different type for capital, fields and habitus (Ozbilgin and Tatli, 2005). The symbolic capital's conceptualization interlinks the objective and subjective features by interlinking the two so that they together develop the shared meanings of worth and value (Ozbilgin and Tatli, 2005). Bort and Kieser (2011) argued that Bourdieu's work is not applicable to all parts of theory because it offers fewer concepts that are only sufficient to define subcategories of theories. 


\section{Issues and Trends in Present Management}

Management theories are subject matter view because there are conflicting and contradictory arguments in favour and against all schools of thoughts. This leads to a situation of which approach to be used by the practitioners in professional work setting. There is no unified management theory, which is the reason Koontz (1961) argued "the management jungle theory". Modern management theorists aimed at higher level of comprehensive and flexible approach, thus, at certain points it collides while other times flow with the scientific and human relations movement. Hence, it is very unlikely to agree upon unification of various management schools of thoughts because they have their own distinctive viewpoints. Sridhar (2017) concludes the reason by stating that, "the problem lies in semantics (everyone saying the same thing but using different terminology), tunnel vision of schools own distinctive viewpoint and differences in definitions of management" (p. 16).

Practitioners have realized the notion that use of the specific approach or style is not based on the rational alone (Lee \& Cassell, 2011). Context is the most important attribute for selection of approach to use the knowledge of distinctive fields as per the requirement and need of the situation (Lee \& Cassell, 2011). With the emergence of globalization, there has been rapid growth in the technologies and interconnectedness that has posed several types of challenges for the managers to deal with the culturally diversified workforce. Additionally, in the recent trends, managers assess themselves as well as the environment in order to select a particular style or approach. However, it is also essential that managers also learn to de-select their style or approach because with the change in the dynamics, it is necessary to use a different approach. In other words, adaptability is important factor in modern day management. The latest challenge for managers also includes the ability to see what suits the employees because having the focus on suiting self would limit their functionality in the complex business world.

Ganson (2013) argued that retention of talent and survival of the business are two important challenges for the managers in the recent times. Viewing those challenges, it is essential that the managers focus on the balanced approach while dealing with the workers in the dynamic and competitively intense business environment. Nowadays, managers and practitioners are less worried about the management's categorization into schools while more focused on the challenges arising in various distinctive situations. However, though, it appears that there is a transcend from traditionalist to modern management school but still the principles of traditionalist and human relations school serve the foundation for dealing with the challenges of complexities, context and connectedness. Management theories have a problem in providing proper explanation as well as the predictions in subject matters that are likely to change drastically in real-life situations (Sridhar, 2017). In modern day, flux and multiplicity combined in the dynamics that creates a challenge for the management theorists to deal with the emerging concepts and subject that have individual as well as collective impact on the work, worker and workplace.

Another inherent challenge is that management's applied science nature could not be separated when opting for managerial and non-managerial implications because all aspects including, organisational design, structure, personalities, group dynamics and learning capabilities vary. Hence, it is a challenge for the managers to operate with a balanced yet effective approach. Not all management theories' applicability could be used for all types of organisations and individuals in all types of situations. The trends of recent times led to the focus on comparative management theory that focused on cross-cultural studies and sub-variations within the cultures such as "across the boundaries between nations or cultural groupings of nations, as well as in the different organisational context" (Sridhar, 2017).

\section{Conclusion}

The scientific management school has focused on the 'one best way' to do task with economic and monetary rewards. This school focused on scientific methods to measure the efficiency. On the other hand, human relations school largely focused on human side of enterprise. It focuses on individual needs that drives people to do well at workplace. It is also concluded that despite changes in the contemporary life still management practices of the modern day revolve around the earlier schools of management including; classical and neo-classical schools of thoughts. There is a shift in paradigm from "task-orientation", "efficiency", "structural patterns" and "one fit for all" to "people-orientation", "effectiveness", "flexibility" and "situational stance". Nevertheless, although, the challenges of the modern-day management appear to be largely altered to some due to increased complexities, context and connectedness, but the management practices are largely driven from the traditionalists and human relations school of thought. The modernity management focused on the cultural aspect such as bridging objectivism and subjectivism through fields, habitus and practices along with the use of power, discipline, conscience and identity to ensure efficiency and effectiveness.

Today the managers are using the pragmatic approach to deal with the contemporary management challenges by using the mix of strategy resulting from the classical and neo-classical schools of management by using the situation as a context, organisation as a system, individual needs as part of organisational humanism, and contingent approach to manage workforce through wide range of managerial practices that are driven from early schools of management.

Lastly, this is established that the purpose of management theories remained on the effective and efficient management of resources in order to retain best talent and survive in the dynamic environment by using the approach and style that is in the best of organisational interest. 
Hussain, N., Haque, A., Baloch, A. / Journal of Yasar University, 2019, 14 (Special Issue), 156-169

\section{REFERENCES}

Alter, S. (2008). Service System fundamentals: Work system, value chain and life cycle. IBM System Journal, 47(1), 7185.

Barile, S., \& Polese, F. (2010). Linking the viable system and many-to-many network approaches to service-dominant logic and service science. Journal of Quality and Service Science, 2(1).

Barnett, T. (2017). Theory $X$ and Theory $Y$ in the Twenty-First Century. Reference for Business Retrieved from: https://www.referenceforbusiness.com/management/Str-Ti/Theory-X-and-Theory-Y.html (Accessed: 10-042019).

Bartol, K.M., \& Martin, D.C. (1998). Management, USA, NY: McGraw Hill.

Bazrkar, A., Heravi, A. J., \& Abedzadeh, M. (2014). The Impact of Postmodernism on Management and Organization Theories, International Journal of Management and Humanity Sciences, 3(8), 2739-2743.

Bort, S., \& Kieser, A. (2011). Fashion in organization theory: An empirical analysis of the diffusion of theoretical concepts. Organization Studies, 32, 655-681.

Bourdieu, P. (2000). Pascalian meditations. Cambridge: Polity Press.

Bourdieu, P. (2003). Participant objectivation. Journal of the Royal Anthropological Institute, 9, $282-294$.

Brown, C. (2014). How Relevant are Fayol's principles of Management Today? Liquid Training. Retrieved from: http://www.liquid-training.co.uk/blog/how-relevant-are-fayols-principles-of-management-today (Accessed: 1004-2019).

Caramela, S. (2018). The Management Theory of Frank and Lillian Gilbreth, Business. Retrieved from: https://www.business.com/articles/management-theory-of-frank-and-lillian-gilbreth/ (Accessed: 10-04-2019).

Caramela, S. (2018). The Management Theory of Mary Parker Follett, Business. Retrieved from: https://www.business.com/articles/management-theory-of-mary-parker-follett/ (Accessed: 10-04-2019).

Cherry, K. (2018). The Hawthorne Effect and Behavioral Studies. VeryWellMind. Retrieved from: https://www.verywellmind.com/what-is-the-hawthorne-effect-2795234 (Accessed: 13-04-2019).

Clegg, S. (1998). Chapter 3: Foucault, Power and Organizations. In Foucault, Management and Organization Theory: From Panoptic on to Technologies of Self, Alan McKinlay and Ken Starkey (Eds). London: Sage publication. DOI: $10.4135 / 9781446221686 . n 3$

Cooper, D. J., Ezzamel, M., \& Robson, K. (2017). The Multiplicity of Performance Management Systems: Heterogeneity in Multinational Corporations and Management Sense-Making, University of Alberta School of Business Research Paper No. 3051551. Retrieved from: https://papers.ssrn.com/sol3/papers.cfm?abstract_id=3051551 (Accessed: 02-05-2019).

Doucet, J. (2017). Theory of Organizational Humanism. Biz-Fluent. Retrieved from:https://bizfluent.com/info-8710096theory-organizational-humanism.html (Accessed: 03-05-2019).

Drucker, P. F. (1963). Managing for Business Effectiveness. Harvard Business Review. Retrieved from: https://hbr.org/1963/05/managing-for-business-effectiveness (Accessed: 10-04-2019).

Ferreira, D., \& Kittsteiner, T. (2011). Competition and Organizational Change. Working Paper, RWTH Aachen University.

Festejo, L. (2012). How Organizational Culture Helps W.L. Gore \& Associates Drive Innovation. Retrieved from: https://www.greatplacetowork.com/publications-and-events/blogs-and-news/973 (Accessed: 14-04-2019).

Furnham A. (2012) Money as a motivator. In: The Talented Manager. Palgrave Macmillan, London. pp. 152-154. DOI: 10.1007/978-0-230-36976-4_41

Ganson, B. (2013). Managing Change in Complex Environment: Questions for Leaders. Sweden: Kombi Nation.

Ghuman, K., \& Aswathapa, K. (2010). Management: Concepts, Practice \& Cases, India, New Delh: Tata McGraw Hill Education Private Limited.

Grandey, A. (2004). Emotions at Work: Theory, Research and Applications for Management. Human Relations, 57(10), 1351-1356.

Grant, R.M., Shani, R., and Krishnan, R. (1994). TQM's Challenge to Management Theory and Practice, Sloan Management Review. Winter, 25-35.

Greenwood, R., \& Meyer, R.E. (2008). Influencing ideas: A celebration of DiMaggio and Powell (1983). Journal of Management Inquiry, 17, 258-264.

Hanks, G. (2017). Examples of Differentiation \& Integration in a Company, Chron. Retrieved from: https://smallbusiness.chron.com/examples-differentiation-integration-company-71759.html (Accessed: 14-042019).

Hanyes, N. M. (2013). Behavior Management: Traditional and Expanded Approaches. USA, NY: University Press of America.

Haque, A. U., Aydin, E., \& Uysal, E. (2017). A Comparison of Effectiveness of Global Leaders and Domestic Leaders in Electronic Retail Industry, Global Journal of Management and Business Research (G), 17(3), version 1, 11-20.

Hitt, Michael A, Middlemist, R Dennis \& Mathis, Robert L. (1979). Effective Management, New York, USA: West Publishing Company. 
Hersey, P., \& Blanchard, K. H. (1969). Life Cycle Theory of Leadership, Training and Development Journal, $23,26-34$. Herzberg, F. (1966). Work and the Nature of Man. Cleveland: World Publishing.

Hodge, S. B. (2002). 21st Century Management: How the game has changed. BedTimes Magazine. Retrieved from: https://bedtimesmagazine.com/2002/11/21st-century-management-how-the-game-has-changed/ (Accessed: 1004-2019).

Islam, J., \& Hu, H. (2012). A review of literature on contingency theory in managerial accounting, African Journal of Business Management, 6(15), 5159-5164. DOI: 10.5897/AJBM11.2764

Katzenbach, J. R., \& Khan, Z. (2010). Money Is Not The Best Motivator, Forbes. Retrieved from: https://www.forbes.com/2010/04/06/money-motivation-pay-leadership-managingemployees.html\#529bda6f3e13 (Accessed: 10-04-2019).

Khuran, A. (2009). Scientific Management: A Management Idea to Reach a Mass Audience, India, New Delhi: Global India Publications PVT Ltd.

Kim, D.H., and Burchill G. (1992). System Archetypes as a Diagnostic toll: a field-based study of TQM implementations. Working Paper No. 07. 005. Cambridge: MIT.

Koontz, H. (1961). The management theory jungle. The Journal of the Academy of Management, 4(3), 174-188.

Lee, B., \& Cassell, C. (2011). Challenges and Controversies in Management Research. New York, USA: Routledge.

Luthans, F., \& Stewart, T. I. (1977). A General Contingency Theory of Management, The Academy of Management Review, 2(2), 181-195.

Koontz, H. (1988). Management, 9th Edition, USA, NY: McGraw Hill Inc.

McGregor, D. (1960). The Human Side of Enterprise. USA, New York: McGraw-Hill Book Company.

McKinlay, A., \& Starkey, K. (1998). Foucault, Management and Organization Theory: From Panoptic on to Technologies of Self, London: Sage publication. DOI: 10.4135/9781446221686.n3

McLeod, S. (2018). Maslow's Hierarchy of Needs, Simply Psychology. Retrieved from: https://www.simplypsychology.org/maslow.html (Accessed: 14-04-2019).

Mele, C., \& Colurcio, M. (2006). The evolving path of TQM: towards business excellence and stakeholder value. International Journal of Quality and Reliability Management, 23(5).

Mele, C., Pels, J., \& Polese, F. (2010). A Brief Review of Systems Theories and Their Managerial Applications. Service Science, 2(1/2), pp. 126-135. DOI: 10.1287/serv.2.1_2.126

Naranjo-Gil, D., Sánchez-Expósito, M. J., \& Gómez-Ruiz, L. (2016). Traditional vs. Contemporary Management Control Practices for Developing Public Health Policies, International Journal of Environmental Research and Public Health, 13(7). DOI: 10.3390/ijerph13070713.

Ng, Irene C.L., Maull, R., \& Yip, N. (2009). Outcome-based Contracts as a driver for Systems thinking and ServiceDominant Logic in Service Science: Evidence from the Defence industry, European Management Journal, 27, 377-387

Nonaka, I., \& Takeuchi, H. (1995). The Knowledge-Creating Company, Oxford University Press, New York.

Ozbilgin, M., \& Tatli, A. (2005). Book Review Essay: Understanding Bourdieu's Contribution to Organization and Management Studies, Academy of Management Review, 30(4), 855-877.

Pham, M., Yu, J., \& Agha, M. (2018). Management Connectedness and Corporate Investment, Asian Finance Association AsianFA) Conference. Retrieved from: https://papers.ssrn.com/sol3/papers.cfm?abstract_id=3108227 (Accessed: 10-04-2019).

Prasad, L., \& Gulshan, S.S. (2011). Management Principles and Practices, India, New Delhi: Excel Books.

Rahman Seresht, H. (1998). Organization and management theories; from modernity to post-modernity. The first volume. Tehran, Iran.

Robbins, S. P., \& Coulter, M. (2012). Management, 11th Edition, USA, NJ: Prentice Hall.

Robinson, M., (2010). Sports Club Management: Manager's leadership style influence by personality, activity. Retrieved from: http://www.humankinetics.com/excerpts/excerpts/managers-leadership-style-influenced-by-personalityactivity (Accessed: 14-04-2019).

Rogers, B. (2006). Behaviour Management: A Whole-School Approach. London, UK: SAGE Publication Inc.

Sheldrake, J. (2003). Henry Gantt and humanized scientific management. Management Theory (2nd ed.). Thompson Learning. pp. 35-43.

Smith, P. G., (2010). Fired up-Leading your organisation to achieve exceptional results. Georgia, USA. 33-37

Splitter, V., \& Seidl, D. (2011). Does practice-based research on strategy lead to practically relevant knowledge? Implications of a Bourdieusian perspective. Journal of Applied Behavioral Science, 47, 98-120.

Sridhar, M. S. (2017). Schools of Management Thought, Retrieved from: https://www.researchgate.net/publication/224952289_Schools_of_Management_Thought (Accessed: 10-042019).

Stros, D., Bukovinski, D., \& Coner, M. (2014). Globalization and management. Economski, Vjesnik. 2, $425-436$. Retrieved from: https://hrcak.srce.hr/ekonomskivjesnik (Accessed: 10-04-2019).

Sullivan, J. (2017). Management Theory of Henry Gantt, Business. Retrieved from: https://www.business.com/articles/management-theory-of-henry-gantt/ (Accessed: 10-04-2019). 
Hussain, N., Haque, A., Baloch, A. / Journal of Yasar University, 2019, 14 (Special Issue), 156-169

Tuttle, a. (2003). What Employees want. Industrial Distribution, 92 (5), 63-67.

Van de Ven AH, Drazin R (1985). The concept of fit in contingency theory. Research in Organizational Behavior, 7(4), 333-365.

Wilson, J. F., and Thomson, A. (2006). Management in Historical Perspective: Stages and Paradigms, Competition \& Change, 10(4). DOI: 10.1179/102452906X160996. 